\title{
Wisdom and Knowledge Will be Given to You*
}

\section{Introduction}

In most cases, confusion results from nothing more than the fact that people make do with fixed, circumscribed views, and do not wish to trouble their intellectual abilities to drift about the entire expanse of an idea in its pristine state. Thus when they introduce, or are under the impression that they are introducing, some thought, they are unable to reconcile it in the least with fundamental things that have been passed down to the nation, and they then argue that the nation must inescapably be torn into factions, even as we see that the perfection of anything is achieved through its unity. ${ }^{1}$

—Rav Abraham Isaac Kook

The present anthology consists of a selection of sources from the time of the talmudic sages until some two generations ago that in some way parallel, resemble, or refer to the fields that figure principally in modern biblical scholarship. ${ }^{2}$

- The first two sections, on the origins of the Torah and of the books of the Prophets and Writings, correspond to the field known as higher, or literary-historical, criticism.

- The third section, on the evolution of the text of the Torah, is in dialogue with the field of lower, or textual, criticism.

- The fourth section discusses the relationship between Scripture and ancient literature, and corresponds to biblical scholarship pursued against the background of the literature of the ancient Near East.

It bears note that this anthology neither offers nor presumes to offer a complete and balanced picture of the views put forth in rabbinic literature on these subjects from the time of the sages until the recent past. Of course, the present compilation shares this problem with all other similar works simply because the vast trove of traditional Jewish literature through the ages far exceeds the bounds of a single anthology, whatever its length may be.

* This collection is dedicated to the blessed memory of my beloved brother Emmanuel Moshe (Ami) Fargeon, who studied the Torah with love and honesty all his life, and passed away at the age of 26 . 
Still, this collection of views is unusual because the sources that it contains have been selected neither for the role that they played in shaping a past or present religious consensus, nor for the esteem that they commanded among rabbinic scholars or the laity. Instead, lest there be any doubt as to the method employed, let it be said unequivocally that the selections within this anthology have been selected on the basis of two key requirements: First, the author of each source was considered to be a member of the rabbinical world (and in recent centuries, of the Orthodox rabbinical world). This criterion, with its emphasis on the identity of the speaker, may come as a surprise to some readers. However, in light of the fact that this anthology seeks to cast some amount of light on the borders of religious discourse, it is a necessary one. The second requirement is that each source correspond to a field of scholarship or to a commonly held view in modern biblical studies, which in turn has two ramifications that the reader should keep in mind. First, the views reflected in this anthology are not necessarily of greater service to religious faith or more plausible to the rational mind than are those views that have not been included. ${ }^{3}$ Second, the opinions found here vary in the degree to which they have gained acceptance in the world of religious thought and exegesis. Some occupy a place at the very heart of the religious consensus (or at least enjoyed such a status at some time in the past) while others have earned both supporters and detractors, and still others defy (or once defied) tenets all but unquestioned in the religious community. ${ }^{4}$

The reader is further advised to take to heart that every selection presented here has been extracted from its original context and transplanted to a new setting. This shortcoming, too, is not unique to the present volume, as the very nature of an anthology is to remove sources from one context and insert them into another. Nevertheless, the problem warrants special attention in this work, with its focus on several of the topics most critical and most sensitive to Jewish biblical exegesis. Text removed from its original context, and sometimes truncated in the process, may lend itself to an imprecise understanding of the view of the scholar quoted; in more than a few instances, the larger context includes qualifications and provisos that are not clearly in evidence in the limited text presented in the anthology. This difficulty is still greater when the selection is placed among others authored by other sages, producing a new context in which the presence of many excerpts permits each to echo further than may have been intended. Thus, the reader would do well not to suffice with reading the selections presented here, but to supplement his knowledge of these scholarly views by studying them in the original context.

Finally, it must be said that the intended meaning of several sources included here is subject to debate, whether in the rabbinical world, between 
rabbinical scholars and academics, or within the academic sphere, and the mere inclusion of a given source in this anthology does nothing to settle any such dispute. Because the purpose of an anthology is to provide readers with the raw textual material, I have not seen fit to deprive the reader of the right (and the duty) that comes with studying this material and independently arriving at his or her own conclusions. ${ }^{5}$

Yet even with all these reservations, these selections make clear that many of the problems identified by academic scholarship of the Bible have been treated by the rabbis and sages throughout the generations, and that some solutions proposed by modern biblical scholars were previously considered, and even adopted, by traditional Jewish sages. It follows that we cannot excuse ourselves from confronting these difficulties, or the answers put to them, by arguing that they emerged only because of the penetration of the yeshiva by foreign influence, ${ }^{6}$ or even as a result of heretical or antisemitic views. ${ }^{7}$

The path available to people of faith as they make their way toward religious truth is far broader than most are accustomed to thinking. Further, and of even greater importance, we see from the sources offered here that traditional Jewish sages neither now have a panacea for these difficulties, nor ever did. What our rabbis did have was a deep faith in God and His Torah that was uncompromised by their intellectual honesty, and a hunger for truth that was not lessened by their faith. ${ }^{8}$ These two virtues together provide us with a range of interpretations from various eras offered by sages who exhibit a great deal of courage and an impressive degree of ingenuity, framed by humility and fear of God.

A few notes are in order with regard to the manner in which the sources are quoted. These texts have been collected from a long list of works authored in various periods, and the reader is advised to bear in mind that not all the information and exegetical proposals appearing in this anthology have withstood the test of time. Often enough, new discoveries and novel fields of study have altered the state of scholarship, or even revolutionized our understanding of the relevant facts. However, because the manner in which these sources contend with the questions that inspired them is of greater importance than any given point that they contain, they have been left in their original form.

The only changes that have been rendered to the sources are intended to facilitate the reader, and generally consist of adjustments to such matters as punctuation. These changes are not marked individually in the text.

The exegetical comments of Rashi, Pseudo-Rashi to Chronicles, Rabbi Joseph Kara, Rabbi Samuel b. Meir (Rashbam), Ibn Ezra, Rabbi Eliezer of Beaugency, Rabbi David Kimḥi (Radak), Rabbi Moses Kimḥi, Rabbi Menahem 
b. Rabbi Simeon, Rabbi Joseph Bekhor Shor, and Nachmanides, unless otherwise noted, have been translated from the texts found in the online version of Mikraot Gedolot ha-Keter (http://mgketer.org).

Texts from Maimonides' Guide of the Perplexed are taken from the English translation by Shlomo Pines (Chicago: University of Chicago Press, 1963). Other works, unless otherwise noted, have been translated from the CD-ROM edition of the Responsa Project, version 22+ (Bar-Ilan University, 2014).

\section{Endnotes}

1. Rabbi Abraham Isaac Kook, Li-Nevukhei ha-Dor [For the perplexed of the generation], ed. Shachar Rachmani (Tel Aviv: Miskal, 2014), 259 (chap. 53); see also 124-126 (chap. 22).

2. The decision not to include material written in the last several decades certainly does not reflect a judgment of any sort as to the nature or importance of these sources or their authors. This choice was made strictly as a means of distinguishing between the debate now unfolding in the Orthodox community, and earlier sources that can enrich and deepen that discussion. Exceptions have been made only for a few sources produced in recent years, each of which is of clear relevance and does not play a role in the current debate.

3. Academic scholars have been known to portray views such as those collected in this anthology as "proto-critism" or "critical" interpretations. Such descriptions, however, are misleading. It is far from clear that these sources mark the start of a true linear process that begins with "proto-criticism" by rabbis and ends in modern biblical criticism. What is more, traditional exegetes were not normally critical in their spiritual posture (or perhaps better, their consciousness), at least in the usual sense of the term. Moreover, while in any number of cases the products of their work appear similar to those of modern biblical criticism, the exegetical tools that they deploy to reach those conclusions are utterly uncritical.

4. This anthology might be regarded as a counterbalance to the censorship sometimes brought to bear in modern editions of works by medieval and early modern traditional scholars to excise ideas deemed problematic. Let suffice as examples the censorship by ArtScroll of the commentary of Rabbi Samuel ben Meir (Rashbam) to Gen. 1 in the recent Czuker Edition Hebrew Chumash Mikra'os Gedolos Sefer Bereishis (New York: ArtScroll Mesorah Publications, 2014), concerning which see Marc B. Shapiro, "Self-Censorship in the Arukh ha-Shulhan, ArtScroll's Latest Betrayal, and Other Assorted Comments," The Seforim Blog, December 10, 2014, http://seforim.blogspot.co.il/2014/12/self-censorshipin-arukh-ha-shulhan.html; Shapiro, "ArtScrol's Response and My Comments," The Seforim Blog, January 14, 2015, http://seforim.blogspot.co.il/2015/01/artscrolls-responseand-my-comments.html. Similar examples are the censorship that editor Isaac S. Lange was forced to exercise in his second edition of the glosses of Rabbi Judah the Pious of Regensburg to the Torah (see note 86 below), and the omission of radical comments made by Rav Abraham Isaac Kook in a volume edited by the Rabbi Zvi Yehuda Kook Institute 
(see note 106 below). Concerning the editing of works authored by Rav Kook, including criticism of the methods employed by the Rabbi Zvi Yehuda Kook Institute, see Meir Munitz, "Hug ha-Re’ayah va-Arikhat Ketavav shel ha-Rav Kook" (Rav Kook's circle and the editing of his writings), 2 vols. (PhD diss., Bar-Ilan University, 2008). See also Rabbi Eitam Henkin, ' 'Li-Nevukhei ha-Dor' mul 'Pinkas mi-Tekufat Boisk' [For the Perplexed of the Generation versus "Journal from the Bauska Period”], "Rav Tza’ir: Maḥshavot va-Hagigim mi-Shulhano shel Rav Kehillah Mathil” [Young rabbi: Thoughts and reflections of a beginner communal rabbi], http://ravtzair.blogspot.co.il/2010/06/blog-post_30.html; Henkin, "'Li-Nevukhei ha-Dor' shel ha-Re'ayah Kook: Mavo le-Hibbur she-Lo Hushlam” [For the Perplexed of the Generation by Rabbi Abraham Isaac Kook: Introduction to an unfinished work], Akdamot 25 (2009/2010): 171-188, especially 171-173.

5. Sources that are unintelligible without running commentary are not included in this anthology. The anthology therefore omits important and relevant discussions, such as the fierce debate over Maimonides' view of the prophecies of Moses and the emergence of the Torah. See Dov Schwartz, Contradiction and Concealment in Medieval Jewish Thought (Ramat Gan, Bar-Ilan University, 2002), 69-80; Micah Goodman, The Secrets of the Guide to the Perplexed (Or Yehudah: Dvir, 2010), 167-187; Alexander Even-Chen, "'I, the LORD, Make Myself Known to Him in a Vision; I speak to Him in a Dream. Not So with My Servant Moses ...? On Moses' Prophecy in Maimonides' Writings," in "New Old Things": Myths, Mysticism and Controversies, Philosophy and Halacha, Faith and Ritual in Jewish Thought through the Ages, ed. Rachel Elior (Jerusalem: Mandel Institute of Jewish Studies, Hebrew University, 2011), 1:181-214.

6. An extreme version of this approach is voiced by Harav Yosef Horvitz in "Whoever Accepts the Yoke of the Torah," a lecture published in the proceedings of a seminar on the addition of a rabbinical school to Yeshivat Midbara K'Eden:

Only if one becomes loose in his attachment to this yoke [viz., of transcendence and fear of God] and thinks he is "fine," so to speak, that he has understood the Torah and is performing its obligations ... then he suddenly has difficulty with the words of the Torah ... and he asks himself, "Why is this section in this place?" According to (his) logic, it should not be. And why did this person do this and another person do that? If I had been in his place, I would not have! ... A person who has that understanding - a person who accepts the yoke of the Torah and understands what Torah is-has no time or leisure to search for these bits of "wisdom," teasing out the meaning and significance of the words of the Torah according to the rules of style and keywords. He does not search the Torah to see whether it speaks as people do, thus lowering the Torah to the level of human language ... but is constantly aware that we do not have a single moment to waste on these things, and everything has to be focused on instruction for the sake of the fear of heaven. This is what all the commentators throughout the generations, all the great sages of the Torah who toiled in their comments on the Torah, toiled to do: to communicate to us these messages of the fear of God.... The more we understand 


\section{Wisdom and Knowledge Will be Given to You}

the demands of the Torah, the less we are affected, at least while we are occupied with the Torah, by the imaginary duty to satisfy some human standard of conduct.

Rabbi Horvitz's complete comments appear as an appendix to Yoshi Fargeon, "Hora'at Sugyot ba-Mikra be-Aspaklaryat Sippur David u-Bat-Sheva" [Teaching issues in the Bible in view of the story of David and Bathsheba] (seminar paper, Herzog Academic College, 2003/2004), 69-71, http://www.herzog.ac.il/vtc/0075519.pdf.

7. Accusations that an opponent lacks religious commitment all too often take the place of material debate within the Orthodox community. It is not impertinent here to recall the comments of Rabbi Naphtali Tzevi Judah Berlin (Netziv), in his introduction to Sefer Bereshit ... im ... Ha'amek Davar, ed. M. Y. Kuperman (Jerusalem: M. Y. Kuperman, 2004/2005), 27-28:

This is because-as explained in the discussion of the verse "The Rock! His deeds are perfect. ... True and upright is He" (Deut. 32:4), in the Song of Moses-God is praised as "upright" to acknowledge the righteousness of God's judgment in destroying the Second Temple, which was [during] a "crooked, perverse generation" (5), because they were righteous and pious and toiled with the Torah but were not upright in their worldly conduct. For this reason, due to the gratuitous hatred in their hearts for each other, they suspected those they saw not following their religious views to be Sadducees or heretics, and as a result came to shed blood ... metaphorically speaking, and to do all other kinds of bad things, to the point that the Temple was destroyed. This was the reason for the acknowledgment of the righteousness of God's justice: that the Holy One, blessed be $\mathrm{He}$, is "upright" and does not tolerate righteous people of this sort, but rather such as walk uprightly, not crookedly, in their worldly conduct as well, even if it [i.e., the unacceptable alternative] is intended for the sake of heaven.

8. This approach is eloquently expressed by Samuel David Luzzatto, S. D. Luzzatto's hebräische Briefe, gesammelt von seinem Sohne Dr Isaias Luzzatto, ed. Eisig Gräber (Przemyśl: typ Zupnik, 1882; Jerusalem: 1966/1967), 1:170: "As for me, just as I love truth and just as I fight my battles without favoring any person or persons, modern or ancient, so do I love the Torah of our God, which is a truthful Torah." Though Luzzatto figures prominently in discussions of the questions addressed by this anthology, his work is omitted in deference to Professor Shmuel Vargon, who ably presents the bulk of the relevant sources in his recent work Shmuel David Luzzatto: Bikoritiut Minutah ba-Perush ha-Mikra [S. D. Luzzatto: Moderate criticism in biblical exegesis] (Ramat Gan: Bar-Ilan University, 2013). See also Ephraim Chamiel, Ha-Derekh ha-Memutza'at: Re'shit Tzemihat ha-Datiyyut ha-Modernit: Teguvot la-Modernah be-Hagut shel Maharatz Chajes, Rabbi S. Rabbi Hirsch, ve-Shadal [The middle way: The emergence of modern-religious trends in 19th-century Judaism: Responses to modernity in the philosophy of Z. H. Chajes, S. Rabbi Hirsch, and S. D. Luzzato] (Jerusalem: Carmel, 2011), esp. 83-117; Yishay Lifshitz, "Haguto shel Shadal be-Parshanuto la-Mikra" [Luzzatto's philosophy and biblical exegesis] (master's thesis, Bar-Ilan University, 2013), especially 47-53. 